\title{
Formation of Long-Term Fiscal Sustainability of Kazakhstan Using the Rule Structural Budget Balance
}

\author{
Sara N. Alpysbayeva1, Shyngys Zh. Shuneyev ${ }^{1}$, Nazigul N. Zhanakova ${ }^{1 *}$, \\ Kuanysh Beisengazin ${ }^{1}$

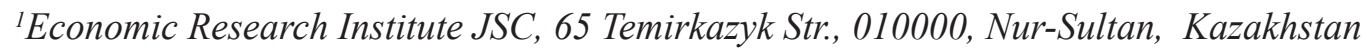

\begin{abstract}
The purpose of the study is to substantiate the potential of using the results of modeling potential GDP and estimating the output gap to comply with fiscal rules that are adequate for the corresponding economic cycle of the economy of Kazakhstan. The methods of economic, statistical, graphical, system, functional analysis, economic and mathematical modeling are applied. To achieve this goal, the analysis of Kazakhstan's fiscal stability was carried out based on the assessment of Kazakhstan's potential GDP and the calculation of output gaps, which were carried out based on the dynamic series method of the reported real GDP in 2005 prices for 1991-2019 using the Hodrick-Prescott filter (CP) using the EViews 10 econometric package. The current mechanism for using the output gap indicator in Kazakhstan's fiscal policy does not have sufficient flexibility. For a timely response of the budget system to changes in the economic situation in the country or abroad, considering the output gap, it is important to introduce an automatic adjustment system that can eliminate contradictions and inconsistencies when making macroeconomic policy decisions by the main regulator and the government of the country. To do this, there is a need to revise the existing fiscal policy based on building a system of new budget rules on countercyclical principles.

The proposed alternative fiscal model with the introduction of the rule on the structural balance of the budget is aimed at ensuring long-term fiscal stability, which does not allow for a pro-cyclical policy.
\end{abstract} impulse.

Keywords: countercyclical policy, government budget, budget rules, potential GDP, output gap, modeling, fiscal

For citation: Alpysbayeva, S.N., Shuneyev, S.Zh., Zhanakova, N.N. \& Beisengazin, K. (2021).Formation of LongTerm Fiscal Sustainability of Kazakhstan Using the Rule Structural Budget Balance. Economics: the Strategy and Practice, 16(3),117-127, https://doi.org/10.51176/1997-9967-2021-3-117-127

* Corresponding author: Nazigul N. Zhanakova - Candidate of Economic Sciences, Associate Professor (Associate Professor), Senior expert, Economic Research Institute JSC.,65 Temirkazyk Str., 010000, Nur-Sultan, Kazakhstan +7 7772734303, e-mail: nazikzhan@mail.ru

Conflict of interests: the authors declare that there is no conflict of interest

Financial support: The article was prepared within the framework of the scientific grant «Development of priorities of countercyclical and structural policies of Kazakhstan with modeling of potential GDP and output gap with decarbonization and shifts in global demand», funded by the Science Committee of the Ministry of Education and Science of the Republic of Kazakhstan, IRN AP08856201.

The article received: 07.04 .2021

The article approved for publication: 25.05 .2021

Date of publication: 30.09 .2021 


\title{
Кұрылымдық бюджеттік баланс ережесін қолдана отырып, Қазақстанның ұзақ мерзімді бюджеттік тұрақтылығын қалыптастыру
}

\author{
Алпысбаева С.Н. ${ }^{1}$ Шунеев Ш.Ж. ${ }^{1}$ Жанакова Н.Н. ${ }^{*}$, Бейсенгазин К.С. ${ }^{1}$ \\ '«Экономикалық зерттеулер институтыл» АҚ. Темірқазық к-сі 65, 010000, Нұр-Сұлтан, \\ Қазақ̧стан
}

Түйін

Зерттеудің мақсаты әлеуетті ЖІӨ модельдеу нәтижелерін пайдалану әлеуетін негіздеу және Қазақстан экономикасының тиісті экономикалық цикліне барабар фискалдық ережелерді сақтау үшін шығарылымның алшақтығын бағалау болып табылады. Экономикалық, статистикалық, графикалық, жүйелік, Функционалдық талдау, Экономикалық- математикалық модельдеу әдістері қолданылды. Қойылған мақсатқа қол жеткізу үшін Қазақстанның әлеуетті ЖІӨ-ін бағалау және шығару алшақтықтарын есептеу негізінде Қазақстанның фискалдық орнықтылығына талдау жүргізілді, ол 1991-2019 жылдардағы бағамен есепті нақты ЖІӨ-нің серпінді қатарларының әдісін қолдану негізінде, Eviews 10 эконометрикалық пакетінің көмегімен ХодрикПрескотт сүзгісін (СП) қолдана отырып, жүргізілді.Қазақстанның фискалдық саясатында шығарылымның ажырау көрсеткішін пайдаланудың қолданыстағы тетігі жеткілікті икемділікке ие емес. Шығарылымның алшақтығын ескере отырып, елдегі немесе одан тыс жерлердегі экономикалық жағдайдың өзгеруіне бюджет жүйесінің уақтылы жауап беруі үшін негізгі реттеуші мен ел Үкіметі макроэкономикалық саясат шешімдерін қабылдаған кезде қайшылықтар мен сәйкессіздіктерді жоя алатын автоматты түзету жүйесін енгізу маңызды. Бұл үшін контрциклдік қағидаттарда жаңа бюджеттік ережелер жүйесін құру негізінде қолданыстағы фискалдық саясатты қайта қарау қажеттілігі туындайды. Бюджеттің құрылымдық теңгерімі жөніндегі ережені енгізе отырып, ұсынылып отырған баламалы фискалдық модель циклдік саясатқа жол бермейтін ұзақ мерзімді фискалдық орнықтылықты қамтамасыз етуге бағытталған.

Түйін сөздер: контрциклдік саясат, мемлекеттік бюджет, бюджеттік ережелер, потенциалды ЖІӨ, өндіріс айырмашылығы, модельдеу, фискалдық импульс.

Дәйексөз алу үшін: Алпысбаева С.Н., Шунеев Ш.Ж., Жанакова Н.Н., Бейсенгазин К. С. (2021). Құрылымдық бюджеттік баланс ережесін қолдана отырып, Қазақстанның ұзақ мерзімді бюджеттік тұрақтылығын қалыптастыруу. Экономика: стратегия және практика, 16(3), 117-127, https://doi.org/10.51176/1997-9967-20213-117-127

* Хат-хабаршы авторы: Жанакова Назигуль Нурлановна - экономика ғылымдарының кандидаты, қауымдастырылған профессор (доцент), аға сарапшы, «Экономикалық зерттеулер институты» АҚ. Темірқазық к-сі 65, 010000, Нұр-Сұлтан, Қазақстан, +7 7772734303, e-mail: nazikzhan@,mail.ru.

Мүдделер қақтығысы: авторлар мүдделер қақтығысының жоқтығын мәлімдейді.

Қаржыландыру. Мақала Қазақстан Республикасы Білім және ғылым министрлігінің Ғылым комитеті, АР08856201 қаржыландыратын «Қазақстанның контрциклдық және құрылымдық саясатының басымдықтарын әлеуетті ЖІӨ-ні және жаһандық сұраныстың декарбонизациясы мен жылжуы кезіндегі шығарылымның алшақтығын моделдей отырып әзірлеу» ғылыми грантын орындау шеңберінде әзірленген.

Мақала редакцияға түсті: 07.04.2021

Жариялау туралы шешім қабылданды: 25.05.2021

Жарияланды: 30.09 .2021 


\title{
Формирование долгосрочной фискальной устойчивости Казахстана с применением правила структурного баланса бюджета
}

\author{
Алпысбаева С.Н. ${ }^{1}$, Шунеев Ш.Ж. ${ }^{1}$, Жанакова Н.Н. ${ }^{*}$, Бейсенгазин К.С. ${ }^{1}$ \\ ${ }^{1} A O$ «Институт экономических исследований», ул. Темірқазық 65, 010000, Нур-Султан, Казахстан
}

\begin{abstract}
Аннотация
Целью исследования является обоснование потенциала использования результатов моделирования потенциального ВВП и оценки разрыва выпуска для соблюдения фискальных правил, адекватных соответствующему экономическому циклу экономики Казахстана. Применены методы экономического, статистического, графического, системного, функционального анализа, экономико-математического моделирования. Для достижения поставленной цели проведен анализ фискальной устойчивости Казахстана на основе оценки потенциального ВВП Казахстана и расчета разрывов выпуска, которые проведены на основе применения метода динамических рядов отчетного реального ВВП в ценах 2005 года за 1991-2019 годы с применением фильтра Ходрика-Прескотта (ХП) при помощи эконометрического пакета EViews 10. Действующий механизм использования показателя разрыва выпуска в фискальной политике Казахстана не обладает достаточной гибкостью. Для своевременной реакции бюджетной системы на изменения экономической ситуации в стране или за ее пределами с учетом разрыва выпуска важно внедрение системы автоматической корректировки, которая может устранить противоречия и несогласованность при принятии основным регулятором и Правительством страны решений макроэкономической политики. Для этого возникает необходимость пересмотра существующей фискальной политики на основе построения системы новых бюджетных правил на контрциклических принципах. Предлагаемая альтернативная фискальная модель с внедрением правила по структурному балансу бюджета направлена на обеспечение долгосрочной фискальной устойчивости, не допускающей проциклической политики.
\end{abstract}

Ключевые слова: контрциклическая политика, государственный бюджет, бюджетные правила, потенциальный ВВП, разрыв выпуска, моделирование, фискальный импульс.

Для цитирования: Алпысбаева С.Н., Шунеев Ш.Ж., Жанакова Н.Н., Бейсенгазин К.С. (2021). Формирование долгосрочной фискальной устойчивости Казахстана с применением правила структурного баланса бюджета. Экономика: стратегия и практика, 16(3), 117-127, https://doi.org/10.51176/1997-9967-2021-3-117-127

* Корреспондирующий автор: Жанакова Назигуль Нурлановна - кандидат экономических наук, ассоциированный профессор (доцент), старший эксперт, АО «Институт экономических исследований», ул. Темірқазық 65, 010000, Нур-Султан, Казахстан, +7 7772734303, e-mail: nazikzhan@mail.ru

Конфликт интересов: авторы заявляют об отсутствии конфликта интересов.

Финансирование. Статья подготовлена в рамках выполнения научного гранта «Разработка приоритетов контрцикличной и структурной политик Казахстана с моделированием потенциального ВВП и разрыва выпуска при декарбонизации и сдвигах глобального спроса», финансируемого Комитетом науки Министерства образования и науки Республики Казахстан, ИРН АР08856201.

Статья поступила в редакцию: 07.04.2021

Принято решение о публикации: 25.05 .2021

Опубликовано: 30.09 .2021 


\section{Введение}

Приток нефтяных доходов в государственный бюджет и Национальный фонд страны формируют положительный фискальный импульс. Рост внутреннего спроса и расширение потребительских расходов за счет государственных вливаний позволяли поддержать экономический рост, но в отдельные периоды приводили к перегреву экономики выше потенциала, росту инфляционного давления на экономику, угнетению инвестиционной активности.

С учетом меняющихся реалий, связанных с постковидным восстановлением и перезапуском экономического роста, важным встает вопрос проведения контрциклической налогово-бюджетной политики, целью которой является сглаживание разрыва выпуска до уровня потенциального ВВП путем применения фискальных и монетарных мер (правил). Это требует моделирования и оценки таких макроэкономических параметров как «потенциальный ВВП» и «разрыв выпуска». Между тем, эти показатели являются статистически ненаблюдаемыми и в казахстанской практике фискального регулирования не применялись. Оценка потенциального ВВП проводилась экспертами Центра макроэкономических исследований и прогнозирования Института экономических исследований с использованием метода динамических рядов отчетного реального ВВП. Для укрепления контрцикличности фискальной системы Казахстана авторами предлагается альтернативная фискальная модель с внедрением правила по структурному балансу бюджета.

\section{Литературный обзор}

Впервые ввел в научный оборот понятие потенциального выпуска Okun A.M. (1962), который имел в виду уровень производства при полной занятости без инфляционного давления [1]. Подходы Okun A.M. для оценки потенциального выпуска основывались на теории кейнсианства при условии политики полной занятости, к которой стремились в те годы США.

Концепции потенциального ВВП и разрыва выпуска рассмотрены в труде Cotis et al (2005). Cotis et al. обосновал три приоритета использования в макроэкономической политике концепций потенциального ВВП и разрыва:

- регулирование спроса и предложения;

- прогнозирование инфляционных рисков для целей монетарной политики;

- оценка фискального импульса и балансировка государственных доходов и расходов [2].
Blanchard Quah (1989) для оценки потенциального выпуска и разрыва выпуска применил SVAR модель с долгосрочными идентификационными ограничениями, основанными на экономической теории [3].

Romer D. (1996) в рамках неоклассического подхода, определил потенциальный выпуск как уровень ВВП, при котором в экономику включаются все факторы производства с реально сложившимся уровнем использования производственных мощностей [4]. При этом, разрыв выпуска он характеризует как отклонения от потенциального объема производства (совокупного предложения) под влиянием изменений совокупного спроса.

Особенно часто для оценки разрыва ВВП экспертами применяется одномерный фильтр Ходрика-Прескотта (Hodrick, Prescott, 1997) [5]. Он основан на декомпозиции временного ряда на тренд и цикл с использованием двухстороннего метода скользящего среднего, и может применяться почти во всех эконометрических пакетах. Вместе с тем, этот метод имеет и недостатки, в их числе чрезмерное сглаживание структурных сдвигов и вероятность получения ложной цикличности.

Razin (2004) определяет потенциальный выпуск как уровень без инфляционного роста при полностью гибких ценах и заработных платах [6].

Harvey (2011) выявил зависимость между инфляцией и разрывом выпуска (кривая Филлипса), применяя одномерную и многомерную модели с ненаблюдаемыми компонентами [7].

Экспертами Института народнохозяйственного прогнозирования РАН (2020) разработана модель пространства состояний, позволяющая прогнозировать потенциальный ВВП и разрыв выпуска с учетом специфики экономики России [8].

Совместное исследование, проведенное экспертами Германии и Беларуси (2014), показало, что «... разрывы выпуска, оцененные при помощи одномерных и многомерных моделей с ненаблюдаемыми компонентами, ... превосходят по своим прогностическим способностям авторегрессионные модели, взятые в качестве базы сравнения» [9].

МВФ (2012) ретроспективно оценил разрыв между фактическим и реальным объемом производства для стран СНГ, в том числе для Казахстана с позиций уязвимости к внешним шокам и рискам роста инфляции.

В 2018 году текущую оценку долгосрочного потенциального роста для стран 
ЕАЭС с использованием модели Солоу провела Евразийская Комиссия ${ }^{1}$.

В работе Andrei A.-N. (2014) с помощью метода производственной функции к годовому временному ряду, покрывающему 1991-2012 годы, и с использованием фильтра ХодрикаПрескотта, и полосовых фильтров КристианоФицджеральда, и Бакстер-Кинг, определен потенциальный ВВП и разрыв выпуска (на примере Румынии) [10].

В работе Fedderke J.W., Mengisteab D.K. (2017) представлена оценка разрыва производства и потенциальных темпов роста в Южной Африке с применением нескольких фильтров. Оценка потенциальных темпов роста в Южной Африке представлена за период 1960-2015 годы. Авторами выявлено, что показатели потенциального объема производства очень чувствительны к различным методологиям. Текущие оценки потенциальных темпов роста находятся в диапазоне 1,9-2,3\% [11].

В работе Casey E. (2018) представлена оценка разрыва выпуска в Ирландии, имеющего значение для налогово-бюджетной политики. В отличие от стандартных подходов, авторы фокусируются на показателях внутренней экономической активности, учитывая ее относительно более богатый налогами характер. Авторами изучены и протестированы различные методы, основанные на одномерных / многомерных фильтрах, а также на анализе основных компонентов, сравнивая собственные оценки с оценками общесогласованной методологии EC [12].

\section{Методы исследования}

При написании статьи были использованы результаты анализа специальной научной литературы по исследуемой теме. Исследование носит аналитический характер c применением методов экономикоматематического моделирования.

Эмпирической базой являются официальные статистические данные Бюро национальной статистики АСПиР и Министерства финансов РК.

Структурный баланс бюджета определяется как баланс бюджета, который имел бы место при потенциальном объеме выпуска в отсутствие циклических колебаний ВВП.

Для расчета структурного баланса решались следующие задачи:

\footnotetext{
1 IMF. (2012), October. World Economic Outlook: a survey by the staff of the International Monetary Fund.
}

а) расчет потенциального выпуска и разрыва ВВП;

б) расчет чувствительности баланса бюджета к разрыву выпуска; баланса.

в) расчет непосредственно структурного

Оценка потенциального ВВП и расчет разрывов выпуска проведены на основе применения метода динамических рядов отчетного реального ВВП в ценах 2005 года за 1991-2019 годы с применением фильтра Ходрика-Прескотта (ХП) при помощи эконометрического пакета EViews 10. С применением фильтра Ходрика-Прескотта рассчитаны разрывы ВВП Казахстана, которые определяются как разность между уровнем фактического и потенциального ВВП.

\section{Результаты и обсуждения \\ 1. Риски фискальной устойчивости в экономике Казахстана.}

С 2007 года значительные объемы трансфертов из Национального Фонда РК и поток нефтяных экспортных пошлин в государственный бюджет позволяли наращивать фискальный импульс в сложные для Казахстана периоды. Рост внутреннего спроса за счет увеличения государственных расходов стимулировал экономический рост. Увеличивающиеся государственные расходы приводят к проблемам фискальной устойчивости, создавая долговую нагрузку, и приводя к нестабильности финансовой системы.

Наряду с позитивными эффектами массированная антикризисная политика и широкое использование средств Национального Фонда привели к росту роли государства как макроэкономического агента практически во всех сферах экономики [13]. Государство берет на себя рыночные риски, связанные c неизбежными антикризисными мерами, создавая настрой огосударствления экономики.

В период пандемии 2020 года общий пакет антикризисных мер Казахстана, не считая налоговых преференций и поддержки на местном уровне, был расширен до 6,3 трлн. тенге и учтен в рамках уточнения республиканского бюджета на 2020 год (таблица 1).

Пакет антикризисных мер включил в себя налоговые стимулы и фискальные меры на сумму 3,9 трлн. тенге за счет республиканского бюджета и 2,4 трлн. тенге за счет внебюджетных средств.

Финансирование дополнительных расходов РБ осуществляется за счет:

- компенсации потерь доходов Республиканского бюджета на 1,7 трлн. тенге; 
- финансирования Дорожной карты занятости на 1,0 трлн. тенге;

- индексации социальных выплат на 267,4 млрд. тенге;

- расширения госпрограмм на 211,3 млрд. тенге;

- компенсации потерь местных бюджетов на 237 млрд. тенге;
- противоэпидемиологических мероприятий, др. расходов по обеспечению безопасности, поддержанию граждан на 486,3 млрд. тенге.

При этом расходы РБ увеличиваются на 3902 млрд. тенге в рамках контрциклической политики.

Таблица 1 - Пакет антикризисных мер Правительства РК на 2020 год

Table1 - Package of anti-crisis measures of the Government of the Republic of Kazakhstan for 2020

\begin{tabular}{|c|c|}
\hline Направления & Сумма \\
\hline Компенсация потерь доходов Республиканского бюджета & 1,7 трлн. тенге \\
\hline Финансирование Дорожной карты занятости (РБ: облигации АО «НУХ «Байтерек») & 1 трлн. тенге \\
\hline $\begin{array}{l}\text { Льготное кредитование МСБ (НБ: оборотный капитал под 8\%, «Экономика простых } \\
\text { вещей» под 6\%) }\end{array}$ & 1 трлн. тенге \\
\hline Жилищное строительство (Облигации НУХ «Байтерек»: расширение до 15 млн. кв.м) & 390 млрд. тенге \\
\hline $\begin{array}{l}\text { Выплаты по потере доходов (ГФСС: ежемесячные выплаты до 4,6 млн. чел на 3,5 } \\
\text { месяца) }\end{array}$ & 476 млрд. тенге \\
\hline $\begin{array}{l}\text { Индексация социальных выплат (РБ: пенсии, пособия, АСП, стипендии, зарплата } \\
\text { КНБ, возмещение комм. услуг) }\end{array}$ & 267,4 млрд. тенге \\
\hline Расширение госпрограмм (РБ: Еңбек, АПК, Ауыл-Ел бесігі, ДКБ) & 211,3 млрд. тенге \\
\hline Компенсация потерь местных бюджетов (РБ: в связи с поддержкой МСБ) & 237 млрд. тенге \\
\hline $\begin{array}{l}\text { Противоэпидем. мероприятия, др. расходы по обеспечению } \\
\text { поддержанию граждан (РБ: борьба с коронавирусной инфекцией) }\end{array}$ & 486,3 млрд. тенге \\
\hline $\begin{array}{l}\text { Расходы в связи с ростом обменного курса, организация дистанционного обучения и } \\
\text { пополнение госматрезерва }\end{array}$ & 577,6 млрд. тенге \\
\hline Итого & 6,3 трлн. тенге \\
\hline
\end{tabular}

Примечание - Из выступления Премьер-министра РК А. Мамина на расширенном заседании Правительства с участием Президента К. Токаева // https://primeminister.kz/ru/news/vystuplenie-premer-ministra-rk-a-mamina-narasshirennom-zasedanii-pravitelstva-s-uchastiem-prezidenta-k-tokaeva-2605733

Приведенные выше меры были необходимы для поддержки наиболее пострадавших секторов экономики, а также предотвращения более глубокой рецессии экономики.

Таким образом, к основным рискам фискальной устойчивости в экономике Казахстана относятся:

- завышение «цены отсечения» нефтяных цен при формировании бюджета в отдельные периоды, когда она превышала реально сложившиеся в тот период мировые цены на нефть, а нефтяные поступления в бюджет намного превышали нефтяные поступления в НФ РК;- рост государственных расходов, в том числе за счет дополнительных трансфертов из Нацфонда РК, направленных на реализацию государственных программ, поддержку МСБ связанную с кредитованием экономики; массированные антикризисные меры, и др.;
- рост зависимости государственных финансов от нефтяной ренты, рост подверженности экономики страны внешним шокам;

- изменение роли государства в качестве макроэкономического агента практически во всех сферах экономики, приводящее к огосударствлению экономики.

2. Институциональная основа фискальной политики Казахстана.

В настоящее время в Республике Казахстан применяется 4 группы бюджетных правил, посредством которых таргетируются фискальные индикаторы: правила бюджетного баланса, правила долга, правила расходов и правила сберегательного механизма НФ РК.

1. Правила бюджетного баланса

Ограничение ненефтяного дефицита госбюджета:

○ Концепция формирования и использования средств НФ РК от 08.12.2016 г. 
○ Пороговое значение - 7,0\% к ВВП.

○ 2019 год - 8,0\% к ВВП (2020 год $11,6 \%)$

Ограничения по дефициту государственного бюджета:

○ Концепция новой бюджетной политики РК №590 от 26.06.2013 г.

○ Пороговое значение $1,0 \%$ к ВВП.

○ 2019 год - $1,8 \%$ к ВВП (2020 год - 4,0\%);

Поступления прямых налогов от предприятий нефтяного сектора в НФ:

○ Концепция формирования и использования средств НФ РК от 08.12.2016 г.

○ Бюджетный Кодекс РК.

2. Правила долга

Правило внешнего долга:

○ Концепция новой бюджетной политики РК №590 от 26.06.2013.

○ Пороговое значение внешнего долга: $100 \%$ к ВВП.

○ 2019 год - 86,3\% к ВВП (оценка на 2020 год - 95,1\%);

Государственный долг и долг квазигоссектора:

○ Концепция новой бюджетной политики РК №590 от 26.06.2013.

○ Пороговое значение: $60 \%$ к ВВП.

○ 2019 год - 49,2\% к ВВП (оценка на 2020 год $-57,8 \%$ );

Государственный долг (в т.ч. Правительства):

○ Концепция новой бюджетной политики РК №590 от 26.06.2013.

○ Пороговое значение: $27 \%$ (25) к ВВП.

○ 2019 год - $23,7 \%(18,5)$ к ВВП $(2020$ год $-29,4 \%(23,8 \%))$; ления:

Долг сектора государственного управ-

○ Договор о ЕАЭС от 29 мая 2014 года.

○ Пороговое значение: 50\% к ВВП.

○ 2019 год - 23,7\% к ВВП (2020 год $29,4 \%)$.

Внешний долг Правительства (с учетом внешнего гарантированного государством долга) и внешний долг квазигоссектора:

○ Концепция формирования и использования средств НФ РК от 08.12.2016.

○ Пороговое значение: не должен превышать валютные активы НФ РК. 2019 года - 33,8 млрд. долларов < валютных активов НФ РК - 61,75 млрд. долларов) (оценка на 2020 год - 40 млрд.\$ (долг) $<58,74$ млрд.\$ (активы НФ));

Расходы на обслуживание и погамение правительственного долга:

○ Концепция формирования и использования средств НФ РК от 08.12.2016.
○ Пороговое значение: $15 \%$ доходов республиканского бюджета (включая трансферты из НФ).

$$
\text { ○ } 2019 \text { года - 12,9\% (2020 год - 13,1\%). }
$$

\section{3. Правила расходов}

Гарантированный трансферт:

○ Концепция формирования и использования средств НФ РК от 08.12.2016.

○ Пороговое значение: 2 трлн. тенге.

○ 2019 года - 2,7 трлн. тенге (2020 год 4,77 трлн. тенге);

Целевой трансферт:

○ Концепция формирования и использования средств НФ РК от 08.12.2016.

○ Пороговое значение: по решению Президента РК.

○ 2019 год - 370 млрд. тенге.

4. Сберегательный механизм НФ РК

Неснижаемый остаток средств НФ РК:

○ Концепция формирования и использования средств НФ РК от 08.12.2016.

○ Пороговое значение: $30 \%$ к ВВП.

○ 2019 год - 39,5\% к ВВП (2020 год $39,5 \%$ к ВВП).

Но эти правила, практически, в последний период времени не соблюдались в полном объеме. Кроме того, они не имеют и контрциклических свойств, т.к. не учитывают состояние текущего цикла экономического роста.

В результате, например, по итогам 2020 года, из действующих 12 бюджетных правил не соблюдаются 5 правил (ненефтяной дефииит госбюджета, дефииит госбюджета, трансферты из НФ, госдолг и расходьь на обслужсивание и погашение правительственного долга), а 2 правила (внешний долг страны, госдолг и долг КГС) близки к нарушению.

Неисполнение бюджетных правил привело к росту рисков и дисбалансов в фискальной сфере:

○ более $40 \%$ доходов государственного бюджета Казахстана, включая трансферты из НФ РК и экспортные таможенные пошлины, формируется за счет природной ренты;

○ размеры трансфертов из НФ РК в бюджет превысили поступления от нефти в НФ РК:

○ налоговые поступления в Национальный Фонд РК после 2014 года стали сокращаться;

○ снижаются объемы поступлений в НФ РК от энергетического экспорта.

Из проведенного анализа можно сделать вывод, что действующие бюджетные правила 
не обеспечивают фискальную устойчивость страны. Это требует пересмотра существующей фискальной политики на основе построения системы новых бюджетных правил на контрциклических принципах.

3. Действующий механизм использования показателя разрыва выпуска в фискальной политике Казахстана.

В Казахстане оценку параметров потенциального ВВП и разрыва выпуска, в рамках монетарной политики, периодически проводит Национальный Банк РК при принятии решения об изменении базовой ставки. Так, 09.09.2019 г. повышение ставки до 9,25\% годовых было обосновано следующим: «на фоне роста потребительского и инвестиционного спроса разрыв выпуска, т.е. разница между фактическим и потенциальным объёмом ВВП на прогнозном горизонте будет находиться в положительной зоне, сигнализируя о наличии проинфляционного давления в экономике» ${ }^{2}$.

Между тем, Министерством финансов и Министерством национальной экономики Казахстана оценки потенциального ВВП и разрыва выпуска, с целью определения фискального импульса, не проводятся. При прогнозировании объема гарантированного трансферта из Национального Фонда, правительство ограничивается использованием показателя ненефтяного дефицита бюджета.

В результате, действующий механизм установления фискального импульса в Казахстане не обладает достаточной гибкостью. Необходима система автоматической корректировки, которая будет способствовать своевременной реакции бюджетной системы на изменения экономической ситуации в стране или за ее пределами с учетом разрыва выпуска.

Кроме того, в Казахстане при оценках прогнозного реального ВВП в позициях Правительства РК и Национального Банка РК проявляются противоречия. Так, в начале 2020 года НБ РК опубликовал пресс - релиз: «По обновленным прогнозам социальноэкономического развития Правительства Республики Казахстан, снижение реального ВВП в 2020 году составит $0,9 \%$. В свою очередь, по оценке Национального Банка снижение может достигнуть $1,3 \%$ на фоне более негативных оценок перспектив развития внешнего сектора» ${ }^{3}$. Фактически показатель

\footnotetext{
2 О повышении базовой ставки до 9,25\%. Пресс-релиз № 28. // https://online.zakon.kz/m/ document/?doc_id=34068128.

3 O sohranenii bazovoj stavki na urovne 9,5\%. Pressreliz №16 (.pdf 27/04/2020, 264,44 KB) // https:// nationalbank.kz/?switch=RUSSIAN
}

ВВП Казахстана в 2020 году снизился на $2,6 \%$.

Нестыковки в прогнозировании ключевого макроэкономического параметра (ВВП Казахстана) могут привести к противоречиям и несогласованности при принятии решений макроэкономической политики: Национальным Банком РК в монетарной политике (увеличение/снижение базовой ставки) и Правительством РК в бюджетной политике (рост/сокращение фискального импульса).

4. Оценка потенцильного ВВП Казахстана и расчет разрывов выпуска.

Оценка потенциального ВВП проводилась экспертами Центра макроэкономических исследований и прогнозирования Института экономических исследований с использованием метода динамических рядов отчетного реального ВВП в ценах 2005 года за 19912019 годы с применением фильтра ХодрикаПрескотта (ХП) при помощи эконометрического пакета EViews 10.

В результате оценки потенциального ВВП и расчета разрывов выпуска (рисунок 1) получен показатель степени инфляционного давления в экономике. Он связывает реальную сторону экономики - производство товаров и услуг - с инфляцией. Если фактический ВВП превышает потенциальный, разрыв выражается положительной величиной и инфляция имеет тенденцию к росту. Если фактический ВВП опускается ниже потенциального, разрыв ВВП выражается отрицательной величиной и возникает понижательное давление на инфляцию.

Как видно из рисунка 1 , именно в периоды превышения реального прироста ВВП динамики потенциального ВВП, наблюдается тенденция ускорения инфляции (2005-2007 гг.; 2010-2011 гг.; 2013-2014 гг., 2017 г.) Исключение составляют годы глубокого кризиса, связанного с внешними шоками падения нефтяных цен и девальвацией национальной валюты (2008 г.; 2016 г;; 2020 г.), что вызывало скачкообразный рост инфляции в Казахстане.

Если проанализировать соответствие фискальной политики в Казахстане экономическому циклу, то в 2008-2009 гг. и 2015-2016 гг. налогово-бюджетная политика была контрцикличной и эффективной, с точки зрения преодоления краткосрочных проблем последствий внешних шоков и возвращения к естественному росту. 


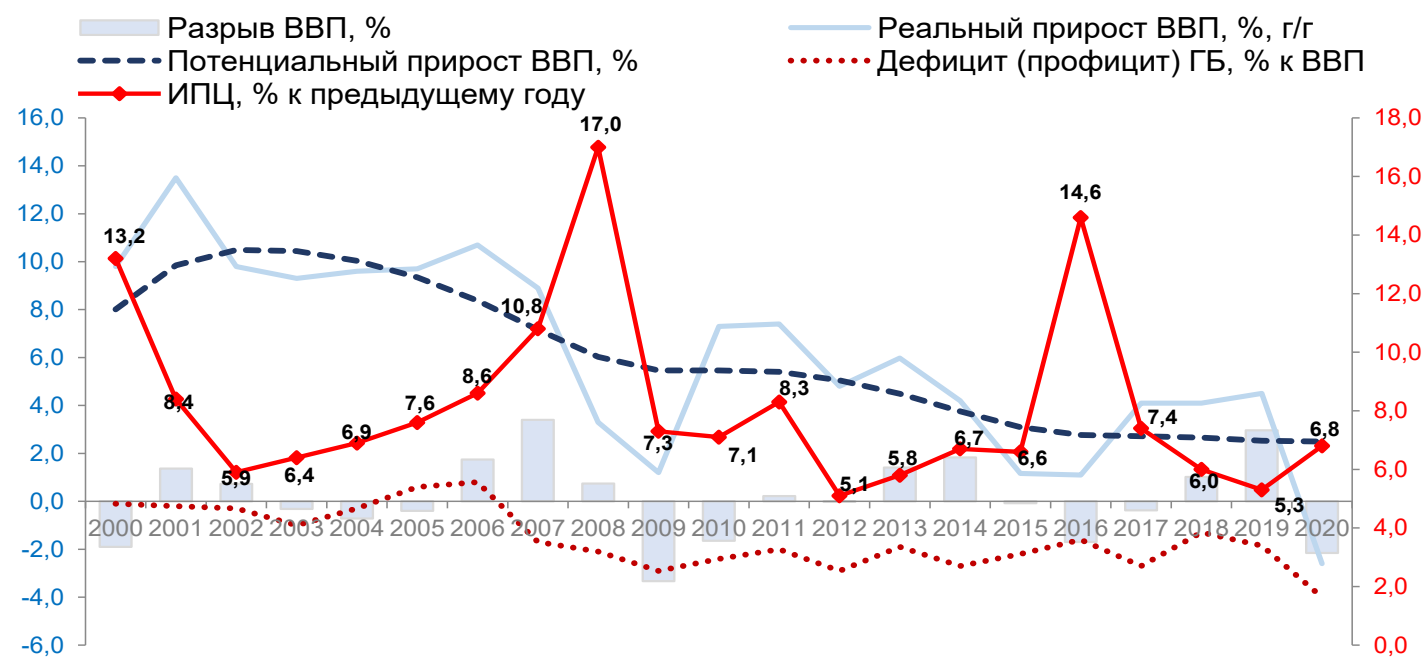

Рисунок 1 - Динамика реального и потенциального ВВП и инфляция Казахстана за 2000-2020 года

Figure 1 - Dynamics of real and potential GDP and inflation in Kazakhstan for 2000-2020

Примечание - Составлено по источнику ${ }^{4}$ расчеты АО «ИЭИ».

Однако в 2005-2007 гг., 2010-2013 гг. (докризисный период) и 2018-2019 гг. политика имела неадекватное экономическому циклу направление: при высоком экономическом росте Правительство сохраняло дефицит бюджета, выделяло значительные средства из НФ РК, то есть политика была проциклической.

В результате, фискальная политика в эти годы была направлена не на сдерживание положительного разрыва ВВП, а, наоборот, способствовала перегреву экономики. Такие несоответствия экономическому циклу указывают на необходимость фискальных правил, которые содержали бы ориентиры эффективности.

В период пандемии 2020 года наблюдается экономический цикл резкого падения реального ВВП ниже его потенциала. Соответственно, разрыв выпуска имеет отрицательный характер. Это потребовало в краткосрочном периоде резкого роста дефицита бюджета и значительного фискального импульса, что соответствовало принципам контрциклической политики.

Таким образом, есть необходимость установить новое правило структурного сальдо бюджета с определением целевого ориентира. Для этого необходимо разработать единый подход к оценке разрыва ВВП и структурного сальдо бюджета в Казахстане.

\footnotetext{
${ }^{4}$ Статистические данные Бюро Национальной статистики АСПиР.
}

\section{Заключение и рекомендации}

Для укрепления стабильности фискальной системы Казахстана предлагается альтернативная фискальная модель с внедрением правила по структурному балансу бюджета.

Структурный баланс бюджета - это номинальное сальдо бюджета, скорректированное на циклическую составляющую бюджета (т.е. циклически скорректированный баланс, соответствующий бюджетному балансу, который мог бы быть зафиксирован, если бы фактический ВВП был равен потенциальному), и за вычетом «одноразовых» и временных мер («oneoffs»).

Такая модель направлена на обеспечение долгосрочной фискальной устойчивости. Она не допускает процикличной политики и предоставляет свободу действий автоматическим стабилизаторам, главным образом, в части доходов.

Модель структурного баланса бюджета основана на балансе бюджета, очищенном от влияния экономического цикла. Данный под-ход позволяет корректировать бюджет с учетом индикаторов, чувствительных к колебаниям делового цикла.

Если исходить из предположения, что налогово-бюджетная политика является эффективным инструментом стабилизации, сальдо бюджета должно реагировать на циклические условия, когда циклические условия отражаются отклонениями ВВП от потенциального объема производства.

Для применения фискальной модели «структурного баланса бюджета» необходим 
непрерывный мониторинг состояния экономики и проведение регулярных профессиональных прогнозов и расчетов:

- эффективной налоговой ставки,

- потенциального ВВП и разрыва выпуска,

- потенциальных налоговых доходов,

- структурного и циклического дефицита,

- определение фискальной позиции и фискального импульса.

\section{Список использованных источников}

1. Okun, A.M. (1962). Potential GNP: Its measurement and its significance. Proceedings of the Business and Economic. Statistics Section American Statistical Association, P. 98-103. https://doi. org/10.1016/0167-2231(79)90009-5

2. Cotis, J.-Ph., Elmeskov, J., Mourougane, A. (2005). Estimates of Potential Output: Benefits and Pitfalls from a Policy Perspective. OECD Economics Department Working Papers, P.1-27.

3. Blanchard, O.J., Quah, D. (1989). The dynamic effects of aggregate demand and supply disturbances. American Economic Review, 79, pp. 655673.

4. Romer, D. (2018). Advanced Macroeconomics. 4-th edition. New-York, NY: The Mc. GrawHill Companies Inc., 540 p.

5. Hodrick, R.J., Prescott, E.C. (1997). Postwar U.S. business cycles: an empirical investigation. Journal of Money, Credit and Banking, Vol. 29, N1, pp. 1-16.

6. Razin, A. (2004). Aggregate Supply and Potential Output. NBER Working Paper. No10294. pp. $1-19$.

7. Harvey, A. (2011). Modelling the Phillips curve with unobserved components. Applied Financial Economics, 21, pp. 7-17. https://doi.org/10.1080/0960 3107.2011.523169

8. Орлова Е.А., Белоусов Д.Р., Галимов Д.И. (2020). О модели потенциального ВВП и разрыва выпуска для российской экономики. Проблемы прогнозирования, №2, с. 61.

9. Пелипась И., Кирхнер Р., Вебер Э. (2014). Является ли разрыв выпуска полезным индикатором для монетарной политики в Беларуси? Банковский вестник, 11, 1-13.

10. Andrei, A.-N. (2014). Using filters and production function method for estimating output gap and potential GDP for Romania. The Bucharest University of Economic Studies, 1-21.

11. Fedderke, J.W., Mengisteab, D.K. (2017). Estimating South Africa's Output Gap and Potential Growth Rate. South African Journal of Economics, Volume 85, Issue 2, 161-177. https://doi.org/10.1111/ saje. 12153

12. Casey, E. (2019). Inside the "Upside Down": Estimating Ireland's Output Gap. The Economic and Social Review, Vol. 50, №1, pp. 5-34.
13. Alpysbayeva, S.N., Shuneyev, Sh.Zh. (2019). Macroeconomic Effects of Kazakhstan's Anticrisis Policy: Economic Growth and Paternalism. Studies on Russian Economic Development, volume 30, pp. 229 234. DOI: $10.1134 / \mathrm{S} 1075700719020023$

\section{References}

1. Okun, A.M. (1962). Potential GNP: Its measurement and its significance. Proceedings of the Business and Economic. Statistics Section American Statistical Association, P. 98-103. https://doi. org/10.1016/0167-2231(79)90009-5

2. Cotis, J.-Ph., Elmeskov, J., Mourougane, A. (2005). Estimates of Potential Output: Benefits and Pitfalls from a Policy Perspective. OECD Economics Department Working Papers, P.1-27.

3. Blanchard, O.J., Quah, D. (1989). The dynamic effects of aggregate demand and supply disturbances. American Economic Review, 79, pp. 655673.

4. Romer, D. (2018). Advanced Macroeconomics. 4-th edition. New-York, NY: The Mc. Graw-Hill Companies Inc., $540 \mathrm{p}$.

5. Hodrick, R.J., Prescott, E.C. (1997). Postwar U.S. business cycles: an empirical investigation. Journal of Money, Credit and Banking, Vol. 29, N1, pp. 1-16.

6. Razin, A. (2004). Aggregate Supply and Potential Output. NBER Working Paper. No10294.

7. Harvey, A. (2011). Modelling the Phillips curve with unobserved components. Applied Financial Economics, 21, pp. 7-17. https://doi.org/10.1080/0960 $\underline{3107.2011 .523169}$

8. Orlova, E.A., Belousov, D.R., Galimov, D.I. (2020). O modeli potencialınogo VVP i razryva vypuska dlja rossijskoj jekonomiki. Problemy prognozirovanija, №2, s. 61 .

9. Pelipas', I., Kirhner, R., Veber, Je. (2014). Javljaetsja li razryv vypuska poleznym indikatorom dlja monetarnoj politiki v Belarusi? Bankovskij vestnik, 11, $1-13$.

10. Andrei, A.-N. (2014). Using filters and production function method for estimating output gap and potential GDP for Romania. Economic Cybernetics Studies \& Research, 1-21.

11. Fedderke, J.W., Mengisteab, D.K. (2017). Estimating South Africa's Output Gap and Potential Growth Rate. South African Journal of Economics, Volume 85, Issue 2, 161-177. https://doi.org/10.1111/ saje. 12153

12. Casey, E. (2019). Inside the "Upside Down": Estimating Ireland's Output Gap. The Economic and Social Review, Vol. 50, №1, pp. 5-34.

13. Alpysbayeva,S.N., Shuneyev, Sh.Zh. (2019). Macroeconomic Effects of Kazakhstan's Anticrisis Policy: Economic Growth and Paternalism. Studies on Russian Economic Development, volume 30, pp. 229 234. DOI: $10.1134 / \mathrm{S} 1075700719020023$ 


\section{Information about the authors}

Sara N. Alpysbayeva - Doctor of Economics, Professor, Chief Researcher of the Institute of Economic Research JSC., Kazakhstan, e-mail: saranur@mail.ru. ORCID ID: https://orcid.org/0000-0002-6401-6517

Shyngys Zh. Shuneyev - Master of Economics, Deputy Director of the Center for Macroeconomic Research and Forecasting of the Institute of Economic Research JSC, Kazakhstan, e-mail: ch.shuneyev@gmail.com. ORCID ID: https://orcid.org/0000-0003-4091-4555

* Nazigul N. Zhanakova- Candidate of Economic Sciences, Associate Professor (Associate Professor), Senior expert, Economic Research Institute JSC, Kazakhstan, e-mail: nazikzhan@mail.ru. ORCID ID: https://orcid.org/0000-00024593-1197

Kuanysh Beisengazin - Master of Economics, Director of the Center for Macroeconomic Research and Forecasting of the Institute of Economic Research JSC, Kazakhstan, e-mail: beisengazin@gmail.com.

\section{Авторлар туралы мәліметтер}

Алпысбаева Сара Нурбековна - экономика ғылымдарының докторы, профессор Экономикалық зерттеулер институтының АҚ, ғылыми қызметкері, Қазақстан, -mail: saranur@mail.ru. ORCID ID: https://orcid.org/0000$\underline{0002-6401-6517}$

Шунеев Шынгыс Жолдыбаевич - экономика магистрі, директордың орынбасары Экономикалық зерттеулер институтыныңң АҚ, Қазақстан, e-mail: ch.shuneyev@gmail.com. ORCID ID: https://orcid.org/0000-0003-4091$\underline{4555}$

* Жанакова Назигуль Нурлановна - экономика ғылымдарының кандидаты, қауымдастырылған профессор (доцент), Макроэкономикалық зерттеулер және болжамдау орталығының аға сарапшысы Экономикальққ зерттеулер институтының АҚ, Қазақстан, e-mail: nazikzhan@,mail.ru. ORCID ID: https://orcid.org/0000-0002$\underline{4593-1197}$

Бейсенгазин Куаныш Сайлаубекович - экономика магистрі, директор Экономикалық зерттеулер институтының АҚ, Қазақстан, e-mail: beisengazin@gmail.com.

\section{Сведения об авторах}

Алпысбаева Сара Нурбековна - доктор экономических наук, профессор главный научный сотрудник Института экономических исследований, Казахстан, е-mail: saranur@mail.ru. ORCID ID: https://orcid.org/0000$\underline{0002-6401-6517}$

Шунеев Шынгыс Жолдыбаевич - магистр экономики, заместитель директора Центра макроэкономических исследований и прогнозирования Института экономических исследований, Казахстан, e-mail: ch.shuneyev@, gmail.com. ORCID ID: https://orcid.org/0000-0003-4091-4555

* Жанакова Назигуль Нурлановна - кандидат экономических наук, ассоциированный профессор (доцент), старший эксперт Центра макроэкономических исследований и прогнозирования Института экономических исследований, Казахстан, e-mail: nazikzhan@mail.ru. ORCID ID: https://orcid.org/0000-0002-4593-1197

Бейсенгазин Куаныш Сайлаубекович - магистр экономики, директор Центра макроэкономических исследований и прогнозирования Института экономических исследований, Казахстан, e-mail: beisengazin@, gmail.com. 